\title{
Investigating the Optimal Location of Potential Forest Industry Clusters to Enhance Domestic Timber Utilization in South Korea
}

\author{
Heesung Woo ${ }^{1}{ }^{\circledR}$, Hee Han ${ }^{2, *}$, Seungwan Cho ${ }^{1}$, Geonhwi Jung ${ }^{1}$, Bomi Kim ${ }^{3}$, Jiyeon Ryu ${ }^{1}$, \\ Hyun Kyu Won ${ }^{2}$ and Joowon Park ${ }^{1, *}$ \\ 1 School of Forest Science and Landscape Architecture, College of Agriculture and Life Sciences, Kyungpook \\ National University, Daegu 41566, Korea; whs1608@gmail.com (H.W.); one5639@knu.ac.kr (S.C.); \\ alzaki3050@knu.ac.kr (G.J.); yns991022@knu.ac.kr (J.R.) \\ 2 Department of Forest Policy and Economics, National Institute of Forest Science, Seoul 02445, Korea; \\ hkwon@korea.kr \\ 3 Chungnam Forest Environment Research Institute, 110 Sanrimbakmulgwan-gil, Geumnam-Myeon, \\ Sejong Special Self-Governing City 30085, Korea; bm0901@korea.kr \\ * $\quad$ Correspondence: heehan@korea.kr (H.H.); joowon72@knu.ac.kr (J.P.); Tel.: +82-10-3602-8737 (J.P.)
}

Received: 27 July 2020; Accepted: 22 August 2020; Published: 27 August 2020

\begin{abstract}
South Korea has abundant forest resources capable of supplying the domestic wood demand. Despite the extensive forest resources, there is continued uncertainty about the nature, quantity, and quality of the timber contained in any particular forested area. Additionally, some technical, logistic, and economic challenges act as barriers to the expansion of domestic timber utilization. To overcome these limitations and to enhance the domestic timber utilization in South Korea, this study investigated the optimal location of potential forest industry clusters. The potential forest availability was estimated based on localized allometric equations. The integration of the analytical hierarchy process and GIS modeling, including a supply chain that minimizes transportation costs, allowed the identification of optimal forest industry clusters locations that balanced the economic, environmental, and social dimensions within the forest industry supply chain. The study reveals that the estimated potential forest resources availability presented approximately 1 billion $\mathrm{m}^{3}$, including sawlog $\left(474\right.$ million $\mathrm{m}^{3}$ ) and pulpwood grade $\left(541\right.$ million $\left.\mathrm{m}^{3}\right)$. Additionally, 45 percent of the sawlogs and 48 percent of the pup grade wood were produced from the Gangwon and Gyeongsangbuk-do regions. Furthermore, the logistic analysis indicates that ten potential forest industry clusters are best aligned with the optimal socio-economic impacts with minimized timber transportation costs. To identify the optimal size and number of potential forest industry clusters, further studies that consider fixed and variable costs for maintaining the forest industry clusters are required.
\end{abstract}

Keywords: forest industry clusters; optimal location; forest supply chain; domestic timber utilization; forest biomass

\section{Introduction}

The forest industry has faced various challenging issues in the overall forest supply chains [1]. There are issues with the integrated networks composed of raw material suppliers, manufacturing facilities, and transportation providers that work across organizational boundaries to deliver forest products to consumers [2]. Recently, the most developed forest countries in Europe, such as Sweden, Finland, and the Baltic countries, have improved forest supply chains by implementing cost-effective logistics on given facility location [3-5]. The forest industry clusters (FIC) concept has been introduced and applied to examine an efficient forest supply chain that minimizes transportation costs in each 
country [6]. Aiming to optimize the timber value chain, FIC allowed collaboration within the cluster that takes place in the timber supply chain, from timber harvest to final wood utilization [7].

South Korea is well-known for its successful reforestation over the past 50 years, turning barren lands into dense forests across the country [8]. In the 1950s, the average growing stock per hectare in the country was approximately $10 \mathrm{~m}^{3}$. Reforestation efforts have increased the average growing stock to $146 \mathrm{~m}^{3}$ [9], which is above the global average of $129 \mathrm{~m}^{3}$ [10]. Most of South Korea's land is covered with forests that reach an area of approximately 6.4 milliion ha [11,12]. This forest-cover ratio indicates that South Korea is the fourth-highest forested country among the members of the Organization for Economic Cooperation and Development (OECD) [13].

However, the reforestation intensively planted in the 1960s and 1970s has caused the age distribution of Korea's forests to be skewed towards forest stands aged 30 years or over [8], which represent approximately $69 \%$ of the country's total forest area (Figure 1). The majority of these stand has already reached to rotation age. It means that the country has now entered a stage of timber production.

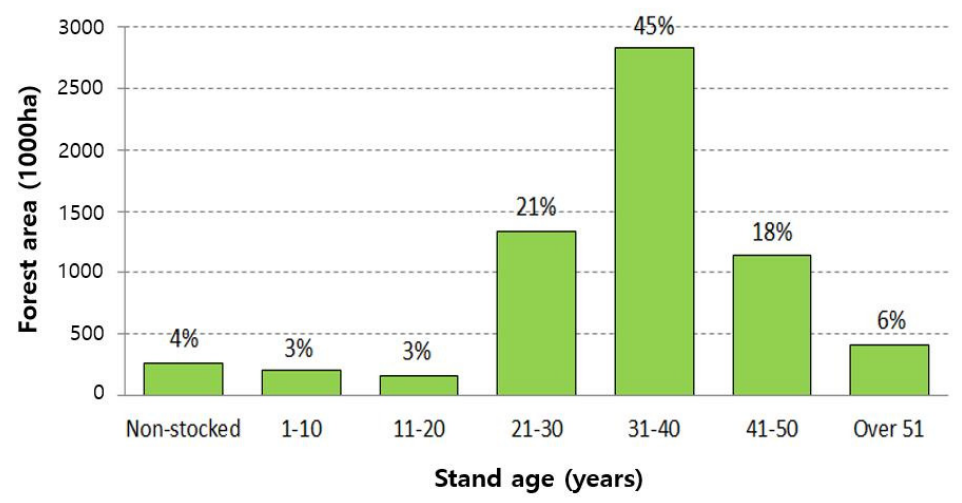

Figure 1. Age distribution of forest stands in South Korea [9]. The "Non-stocked" indicates the areas that include bamboo forests, eroded lands, roads, etc.

Despite the abundant forest resources, South Korea is heavily dependent on imported wood to supply its domestic wood demand [14]. According to the statistical book of forestry in 2019, $85 \%$ of the total wood consumption in South Korea was imported [15]. One of the factors that make this imbalance between timber supply and demand in the domestic market, is that South Korea has lower cost competitiveness in the wood industry compared to other countries, such as Austria and Japan, due to its low density of forest roads and low proportion of planted forests for timber production [16]. Although several previous studies have found evidence for potential domestic timber utilization, some technical, logistic, and economic challenges act as barriers to the domestic utilization expansion [6,17-20].

These challenges point out that: (i) forest sites are highly variable, of unknown timber quality, and widely distributed all over Korea in such a way that it imposes harvesting, processing, and transportation problems that have implications on the economic viability of domestic timber utilization from any specific location; (ii) despite the large volume of forest resources, continued uncertainty exists about the timber nature, quantity, and quality in any particular forest location; (iii) the lack of robust planning prompt concerns about the decreasing profitability of domestic forest entities, highly affected by low productivity and high production cost due to their small business scales [21].

Since transportation is the most critical factor impacting the overall cost of forest supply chains, site selection for FIC in proximity to unutilized forest resources currently available will offer an opportunity to minimize the timber supply cost by providing an optimal location of potential forest industrial areas [22]. Selecting optimal locations of FIC needs to consider environmental and socioeconomic constraints that involve determining the cluster number and scale within the geographical network of connected forest resources, processing facilities, and end-markets [23]. 
GIS modeling is a tool broadly used to investigate forest volume estimation and inventory assessment [24-27], as well as logistic analysis to identify minimal transportation costs based on the least cost distance matrix [28-30]. Additionally, GIS integration with the analytical hierarchy process (AHP) is a preferred approach for investigating the potential location of forest-related facilities and for assessing the relative importance of economic, environmental, and social criteria affecting site selection [30-36]. The AHP analysis is a specific technique that is applied to estimate the factor weighting [37]. The influencing effect of FIC varies from region to region, and to reflect the regional interests, it is necessary to assign them a different relative weight [38].

This study aims to investigate the optimal locations of prospective FIC in South Korea. Integrated GIS and AHP models with logistics simulations were used to identify the best FIC candidate locations with optimal logistic supply chain cost. The results could contribute to the future Korean FIC planning and investment decisions with high efficiency of domestic timber utilization.

\section{Methodology}

The overall research process is presented in Figure 2. Forest resources were estimated by the potential grade of product types, such as sawlog and pulp, based on wood grading standards in Korea [39]. The restriction and suitability models were developed to investigate the potential FIC available land areas. In this phase, integrated GIS and AHP were applied to assign a weight to each main and sub-criterion [40]. All GIS and spatial data were collected or provided by the government and industrial partners, including the Korea Forest Service (KFS), National Institute of Forest Science (NIFOS), Ministry of the Interior and Safety, Ministry of Environment, National Geographic Information Institute, and National Transport Information Center. FIC optimal locations were investigated through three analytical phases, including land availability, land suitability, and location-allocation analysis. In the first phase, the restriction area was removed applying developed restriction model. Then, the potential FIC locations were identified using the suitability model according to a set of specific main and sub-criteria. In the last phase, identified potential FIC locations were simulated using network analysis to investigate the minimization of total transportation cost between the FIC candidate locations and forest resources. The following section describes, in detail, the phase of each analysis.

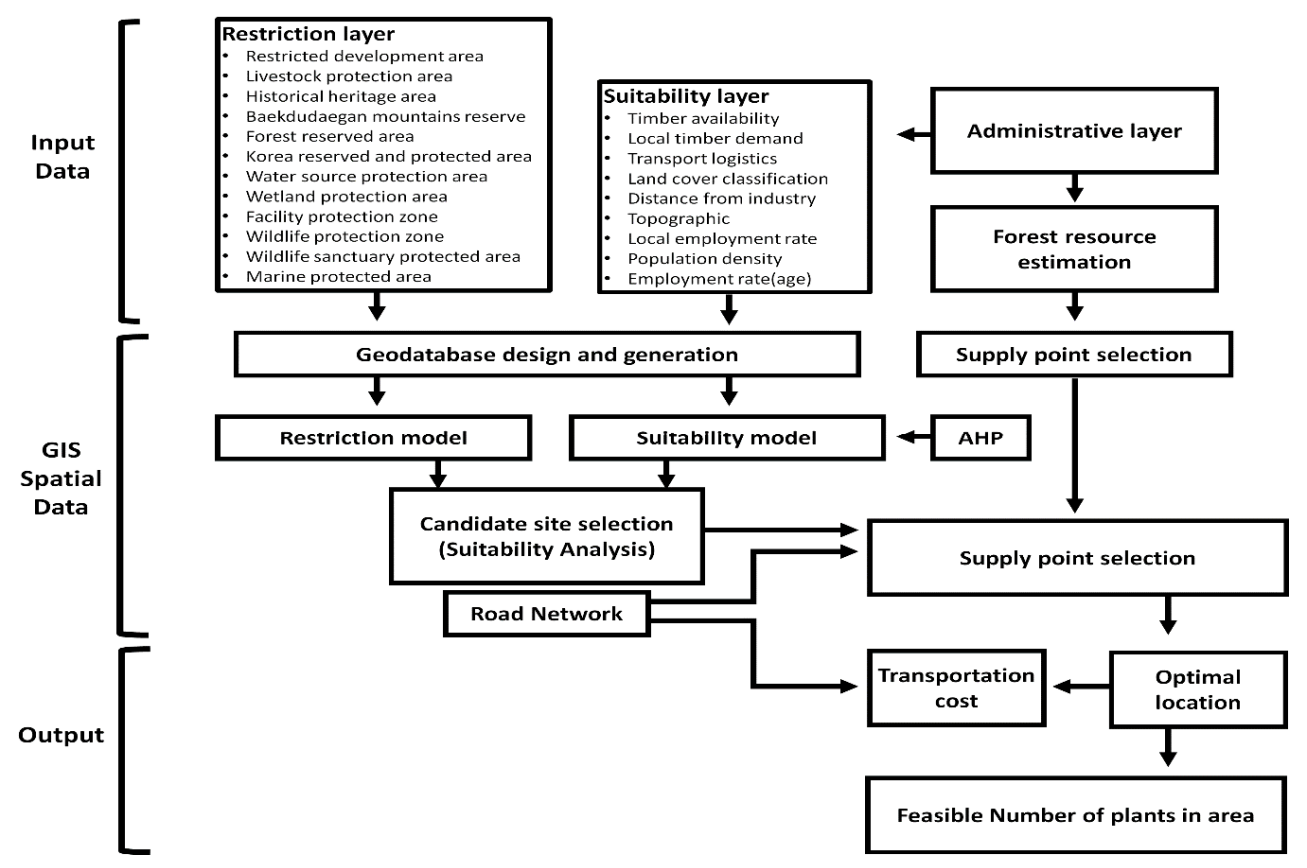

Figure 2. The overall research process in search of optimal locations for potential forest industry clusters areas. 


\subsection{Forest Resources Availability in South Korea}

Table 1 shows the species composition of South Korea's forests. The potential forest availability was estimated using the forest growth and yield model developed by the NIFOS [41]. The details and key assumptions were described in [41-43]. However, estimating the forest resources at the local to regional scales has been hampered by the uncertainty of environmental conditions of the regional forests [44]. To overcome these limitations, the models were developed on local-based forest inventory data, including four major conifer species in the country: Pinus densiflora Siebold \& Zucc., Pinus koraiensis Siebold \& Zucc., Larix kaempferi (Lamb.) Carr., and Pinus rigida Mill. The developed models are presented in Table 2. Equation (1) presents the model estimation of forest resource availability, where $\mathrm{Y}$ is the estimated total volume of forest resources available in the country, $X_{i j}$ is forest stand age for species $i$ in province $j$, and $\alpha_{i j}, \beta_{i j}$ are parameter values to estimate forest volume for species $i$ in province $j$ (Table 2). The required data for forest resource availability estimation were sourced from the Korean Forest Geospatial Information Service’s database [45].

$$
\mathrm{Y}=\sum_{j} \sum_{i}\left(\alpha_{i j} \cdot X_{i j}-\beta_{i j}\right)
$$

Table 1. Tree species composition of South Korea's forests [9].

\begin{tabular}{ccccccccc}
\hline \multirow{2}{*}{ Species } & \multirow{2}{*}{ Total } & \multicolumn{7}{c}{ The Area by Stand Age (1000 ha) } \\
\cline { 3 - 9 } & $(\mathbf{1 0 0 0}$ ha) & Non-Stocked & $\mathbf{1 - 1 0}$ & $\mathbf{1 1 - 2 0}$ & $\mathbf{2 1 - 3 0}$ & $\mathbf{3 1 - 4 0}$ & $\mathbf{4 1 - 5 0}$ & $>\mathbf{5 0}$ \\
\hline Coniferous & 2339 & - & 91 & 60 & 397 & 1172 & 504 & 115 \\
Deciduous & 2029 & - & 76 & 61 & 515 & 829 & 357 & 191 \\
Mixed & 1706 & - & 36 & 39 & 422 & 829 & 276 & 103 \\
Total & 6334 & 261 & 203 & 160 & 1334 & 2830 & 1137 & 409 \\
\hline
\end{tabular}

Table 2. Parameter values for forest volume estimation [41].

\begin{tabular}{|c|c|c|c|c|}
\hline Province & & ecies & $\alpha^{*}$ & $\beta^{* *}$ \\
\hline \multirow{6}{*}{ Gangwon } & \multirow{4}{*}{ Coniferous } & $\begin{array}{l}\text { Pinus densiflora } \\
\text { Siebold \& Zucc. }\end{array}$ & 63.409 & 37.519 \\
\hline & & $\begin{array}{l}\text { Pinus koraiensis } \\
\text { Siebold \& Zucc. }\end{array}$ & 68.681 & 67.668 \\
\hline & & $\begin{array}{l}\text { Larix kaempferi } \\
\text { (Lamb.) Carr. }\end{array}$ & 50.261 & 2.235 \\
\hline & & Pinus rigida Mill. & 60.577 & 3.290 \\
\hline & \multicolumn{2}{|c|}{ Deciduous } & 37.380 & -3.065 \\
\hline & \multicolumn{2}{|c|}{ Mixed } & 60.795 & 45.833 \\
\hline \multirow{6}{*}{ Gyeonggi } & \multirow{4}{*}{ Coniferous } & Pinus densiflora & 51.020 & 18.414 \\
\hline & & Pinus koraiensis & 64.854 & 58.107 \\
\hline & & Larix kaempferi & 40.858 & -23.908 \\
\hline & & Pinus rigida & 58.098 & 20.300 \\
\hline & \multicolumn{2}{|c|}{ Deciduous } & 39.891 & -0.960 \\
\hline & \multicolumn{2}{|c|}{ Mixed } & 58.712 & 40.769 \\
\hline \multirow{6}{*}{ Gyeongnam } & \multirow{4}{*}{ Coniferous } & Pinus densiflora & 49.434 & 21.596 \\
\hline & & Pinus koraiensis & 62.312 & 44.090 \\
\hline & & Larix kaempferi & 52.589 & 15.390 \\
\hline & & Pinus rigida & 57.766 & 27.816 \\
\hline & \multicolumn{2}{|c|}{ Deciduous } & 40.252 & 9.064 \\
\hline & \multicolumn{2}{|c|}{ Mixed } & 45.103 & 15.693 \\
\hline
\end{tabular}


Table 2. Cont.

\begin{tabular}{|c|c|c|c|c|}
\hline Province & & cies & $\alpha^{*}$ & $\beta^{* *}$ \\
\hline \multirow{6}{*}{ Gyeongbuk } & \multirow{4}{*}{ Coniferous } & Pinus densiflora & 51.757 & 27.696 \\
\hline & & Pinus koraiensis & 66.129 & 68.206 \\
\hline & & Larix kaempferi & 49.357 & 8.254 \\
\hline & & Pinus rigida & 54.482 & 21.319 \\
\hline & \multicolumn{2}{|c|}{ Deciduous } & 36.319 & -2.969 \\
\hline & \multicolumn{2}{|c|}{ Mixed } & 52.683 & 31.890 \\
\hline \multirow{6}{*}{ Jeonnam } & \multirow{4}{*}{ Coniferous } & Pinus densiflora & 49.358 & 17.900 \\
\hline & & Pinus koraiensis & 63.658 & 63.331 \\
\hline & & Larix kaempferi & 58.850 & 38.981 \\
\hline & & Pinus rigida & 66.256 & 47.963 \\
\hline & \multicolumn{2}{|c|}{ Deciduous } & 44.670 & 21.006 \\
\hline & \multicolumn{2}{|c|}{ Mixed } & 52.656 & 32.501 \\
\hline \multirow{6}{*}{ Jeonbuk } & \multirow{4}{*}{ Coniferous } & Pinus densiflora & 46.583 & 10.233 \\
\hline & & Pinus koraiensis & 65.630 & 52.956 \\
\hline & & Larix kaempferi & 50.880 & 4.475 \\
\hline & & Pinus rigida & 62.345 & 36.370 \\
\hline & \multicolumn{2}{|c|}{ Deciduous } & 37.500 & 1.088 \\
\hline & \multicolumn{2}{|c|}{ Mixed } & 56.243 & 40.125 \\
\hline \multirow{6}{*}{ Chungnam } & \multirow{4}{*}{ Coniferous } & Pinus densiflora & 44.131 & 6.237 \\
\hline & & Pinus koraiensis & 58.696 & 42.510 \\
\hline & & Larix kaempferi & 47.798 & 7.356 \\
\hline & & Pinus rigida & 55.158 & 22.320 \\
\hline & & uous & 37.167 & 3.603 \\
\hline & & red & 51.003 & 30.027 \\
\hline \multirow{6}{*}{ Chungbuk } & \multirow{4}{*}{ Coniferous } & Pinus densiflora & 48.167 & 16.337 \\
\hline & & Pinus koraiensis & 50.389 & 26.762 \\
\hline & & Larix kaempferi & 48.751 & 4.898 \\
\hline & & Pinus rigida & 60.341 & 28.426 \\
\hline & \multicolumn{2}{|c|}{ Deciduous } & 39.747 & -0.283 \\
\hline & \multicolumn{2}{|c|}{ Mixed } & 56.087 & 32.564 \\
\hline
\end{tabular}

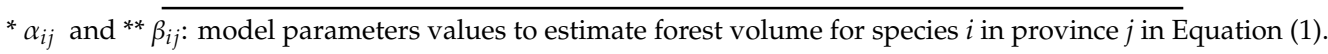

Additionally, to account for forest regimes and harvesting efficiency, the estimation of forest resources availability was limited in the diameter at breast height (DBH) and area by the Korean Forest Harvesting Regulation (KFR) [42]. In this research, the DBH over $18 \mathrm{~cm}$ was only considered as actual usable forest resource as sawlogs in natural forest and plantation forests. Furthermore, forest areas that are less than 5 ha were not included in the estimation due to the inefficiency of forest harvesting and forest ownership. Most of the small scale of forest lands (less than 5 ha) are owned by private sectors, including individual, company, and corporation. In this context, there are some limitations to manage and access the forest land owned by private owners. For these reasons, this research did not include small scale (less than 5 ha) forest lands. Lastly, estimated forest availability was separated into two types of forest products-sawlogs and pulp. The definitions of those two forest products are presented in Table 3. 
Table 3. Definition of forest product types and associated wood grades [42].

\begin{tabular}{cccc}
\hline Forest Product Types & \multicolumn{2}{c}{ Softwood } & Hardwood \\
\hline Diameter $(\mathrm{cm})$ & $\geq 18$ & $<18$ & $>6$ \\
Grade & Sawlogs & Pulp & Pulp \\
\hline
\end{tabular}

\subsection{Restriction Model to Identify FIC Available Area}

The potential location of FIC needs to consider several criteria and constraints, such as geological and environmental factors, which are imposed by national and/or local government regulations. Primarily, land-use conversion and development of industrial areas are strictly regulated within national land-use conversion development regimes [46]. Thus, we considered the geological and environmental constraints to select the potential locations of FIC. These constraints could identify protected and reserved areas where industrial area construction is not allowed (e.g., Baekdudaegan mountains reserve, national park, forest reserved area, wildlife protection area, and urban natural park areas). Restricted buffer zones were then created through proximity analysis. The potential FIC locations were designed only outside the buffer zone.

To develop a restriction model, a list of GIS datasets is described in Table 4. Each GIS restriction layers combined into one single layer as a restriction map, including specific information of constraint values. The vector layer was converted and reclassified into a binary raster data format ( 0 or 1 value). Reclassified binary raster data consisted of binary values, thus areas consisted of "zeros" were classified as restricted area, and areas consisted of "ones" were classified as FIC available areas. The final restriction map was generated by multiplying all reclassified binary raster layers using a raster calculation tool in ArcGIS 10.5 [30,47]. The output of the reclassified map was called "restriction map".

Table 4. List of spatial data used to develop the restriction model.

\begin{tabular}{|c|c|}
\hline \multicolumn{2}{|c|}{ List of GIS Layers to Generate Restriction Map } \\
\hline Baekdudaegan mountains reserve & Riparian buffer zone \\
\hline Country park & Scenic site \\
\hline Ecosystem and landscape conservation area & Special island \\
\hline Environment conservation marine area & Special measure area \\
\hline Fishery resource conservation area & Urban natural park area \\
\hline Forest genetic resources reserve & Water source protection area \\
\hline Marine protected area & Wetland protected area \\
\hline Marine protected area & Wetland protected area-Tidal flat \\
\hline National park & Wildlife protection area \\
\hline Natural environment conservation area & Wildlife special protection area \\
\hline Natural monument & Catchment reserve protection area \\
\hline Nature reserve & Disaster prevention reserve \\
\hline Provincial park & Landscape reserve \\
\hline Restricted development area & Wildlife reserved area \\
\hline Historical heritage area & Native forest reserved area \\
\hline Forest reserved area & Water source protection area \\
\hline Wetland protection area & Native forest reserved area \\
\hline Facility protection zone & Livestock protection area \\
\hline Wildlife protection zone & \\
\hline
\end{tabular}




\subsection{Developing a Suitability Model Using AHP}

The potential locations for FIC candidates were investigated using integrated AHP and GIS techniques to assign the factors a different relative weight $[38,40]$. To evaluate the relative weighted values, the first step was to construct an AHP hierarchical model consisting of two phases, including the main criteria (economic, environmental, and social), each having three sub-criteria. Nine sub-criteria were considered in the suitability analysis. The selected sub-criteria were categorized according to three different characters of main criteria called "economic", "Environmental", and "Social".

For the main criteria's economic factor, timber availability, local timber demand, and transport logistics were analyzed. They were regarded as high correlated sub-criteria with economic influence on the FIC construction. It was assumed that the abundant forest resources within an area would have a higher weighted value compared to an area less abundant in forest resources. The areas with a high local demand for forest resources were also given a high weighted value because areas with high demand for forest resources are more likely to attract FICs. The close distance to roads and FICs also led to high weighted value due to the minimum distance to roads, which can reduce logging transportation costs substantially.

To avoid land-use change issues in the estimation of relative weights of sub-criteria included in the environmental factor, it was preferred to locate FICs in available areas that are legally authorized under Korea's land-use law and regulations to construct FIC. Furthermore, FIC candidate locations closer to industrial areas were preferred because they would have a higher weighted value compared to distant potential FIC candidates. The topographical preference for FIC location was determined to be in a flat area ( 0 to 3 degree) to avoid landslides or erosion that could occur on steep slopes and sites with easily eroded soils. The local employment rate and population density in the local government area were considered in the weighting assignment by the social criteria. A low employment rate was preferred in the construction of FICs that contribute to the local government job creation. Low and middle population density regions were prioritized for improving local economic development. Overall weights were obtained from 15 forestry experts, consisted of the academic, forest industry, forest research institution, and government officer in KFS.

Once the weights were assigned to GIS layers, they were reclassified into raster format $(100 \times$ $100 \mathrm{~m}$ cell size), and the corresponding final suitability map was generated by a weighted linear combination of the overall GIS layers [30]. The applied equation was as follow (Equation (2)):

$$
S_{i}=\sum_{n=1}^{p} w_{n} C_{i n}
$$

where $S_{i}$ is suitability value in the $i$ th cell at the final grid, $w_{n}$ is the weight allocated to the $n$th criterion from the AHP analysis, $C_{i n}$ is the value of the $i$ th cell in the grid of the $n$th layer, and $p$ is the total criteria number in the suitability analysis [48]. The overall criteria values were standardized before using them in the equation. The estimated values Equation (2) in the final output were reclassified into five-level classes where higher values indicated a more suitable location for the potential FIC location. Computed reclassified raster value cells in levels 5 and 4 were identified as the most suitable FIC candidates for potential FIC construction.

\subsection{Identifying the Optimal Location of FIC Using Network Analysis}

The optimal location of FIC was identified using the Network Analysis tool in ArcGIS 10.5. The road network, location of forest resources, and location of potential FIC candidates were needed to simulate location-allocation analysis. The location-allocation analysis calculated transportation distances using an actual road network between FIC candidates and forest resources rather than a radius or straight-line distances. The aim of the analysis (p-median problem solver) was to locate $n$ candidate FICs among $m$ potential selected suitable FIC candidates $(m>n)$ while satisfying several constraints; thus, the distances between each forest resource and FIC location were minimized [49]. 
It automatically identifies the shortest travel distance so that the overall distance between the FIC candidate points $s$ and the set of forest resource points $f$ is minimized (Equation (3)) [48].

$$
\min \sum_{s f} W_{f} d_{s f} x_{s f}
$$

where $w_{f}=$ weight associated with each forest resource location $f, d_{s f}=$ distance between forest resource point $f$ and the potential FIC location s. $x_{s f}=$ one if forest resource point $f$ is allocated to FIC location $s$, otherwise equals zero [48]. The location-allocation tool creates the least cost matrix with the shortest travel distances between FIC candidates and the available forest resource points. This tool was developed with multiple techniques to achieve a near-optimal solution, including vertex substitution heuristic and refining metaheuristic [50]. Logistic costs were calculated based on optimal route travel distance derived from the location-allocation analysis (Equation (4)).

$$
C_{i j}=F C_{i}+2 V C \sum_{k=1}^{M} d_{k}
$$

where $C_{i j}$ is the total transportation cost (United States Dollar-USD per green ton) for the optimal route between the FIC candidate $j$ and forest resource point $i ; F C$ is the fixed cost related to harvesting cost (USD per dry ton) at forest resource point $i ; V C$ is the variable cost associated with traveling distance (USD per ton- $\mathrm{km}$ ); $d_{k}$ is the distance of the traveled road segment $(\mathrm{km})$, and $M$ is the total number of segments along the optimal pathway between the FIC $j$ and the forest resource point $i[30,48]$. In this study, the transportation cost from the logging site to the FIC was only considered to investigate the optimal FIC location and numbers. Other cost components, including fixed and variable costs, were kept at the same rate in the whole country due to the uncertainty of the future harvesting operation and cost. Finally, to investigate the most efficient number of potential FIC construction, six scenarios with a different number of optimal FIC locations and transportation limits were simulated using the location-allocation analysis (Table 5).

Table 5. Six scenarios analyzed to investigate the most efficient number of potential forest industry clusters (FIC) construction.

\begin{tabular}{cccc}
\hline Scenario & $\begin{array}{c}\text { No. of Optimal } \\
\text { Locations }\end{array}$ & Location Code & Constraints \\
\hline 1 & 1 & FIC1A & $\begin{array}{c}\text { No. of potential location: } 1 \\
\text { Transportaion limit (radious): } 500 \mathrm{~km}\end{array}$ \\
\hline 2 & 3 & FIC3A, 3B, 3C & $\begin{array}{c}\text { No. of potential locations: } 3 \\
\text { Transportaion limit (radious): } 200 \mathrm{~km}\end{array}$ \\
\hline 3 & 5 & FIC5A, 5B, 5C, 5D, 5E & $\begin{array}{c}\text { No. of potential locations: } 5 \\
\text { Transportaion limit (radious): } 150 \mathrm{~km}\end{array}$ \\
\hline 5 & 8 & FIC8A, 8B, 8C, 8D, 8E, 8F, 8G, 8H & $\begin{array}{c}\text { No. of potential locations: } 8 \\
\text { Transportaion limit (radious): } 100 \mathrm{~km}\end{array}$ \\
\hline 6 & 10 & FIC10A, 10B, 10C, 10D, 10E, 10F, \\
$10 \mathrm{G}, 10 \mathrm{H}, 10 \mathrm{I}, 10 \mathrm{~J}$ & $\begin{array}{c}\text { No. of potential locations: } 10 \\
\text { Transportaion limit (radious): } 100 \mathrm{~km}\end{array}$ \\
\hline 12 & FIC12A, 12B, 12C, 12D, 12E, 12F, \\
$12 \mathrm{G}, 12 \mathrm{H}, 12 \mathrm{I}, 12 \mathrm{~J}, 12 \mathrm{~K}, 12 \mathrm{~L}$ & $\begin{array}{c}\text { No. of potential locations: } 12 \\
\text { Transportaion limit (radious): } 100 \mathrm{~km}\end{array}$ \\
\hline
\end{tabular}

\section{Results and Discussion}

\subsection{Forest Resources Availability in South Korea}

The estimated forest availability indicated that a large amount of forest resources are available in the form of sawlogs and pulp/energy wood to supply FIC in South Korea. The distribution of potential 
sawlogs and pulp/energy wood availability map is shown in Figure 3. The total estimated sawlog volume is $474,949,000 \mathrm{~m}^{3}$. Pulp/energy wood equals $541,876,000 \mathrm{~m}^{3}$. The largest number of potential forest resources was located in the Gangwon-do region. Gangwon and Gyeongsangbuk-do regions were able to produce about $45 \%$ of the sawlogs and $48 \%$ of the pulp/energy wood (Figure 4 ). Forest resources availability analysis shows that most forest resources could be produced in Northeast Korea, including Gangwon-do, Chungcheongbuk-do, and Gyeongsangbuk-do regions (Figure 4). Compared to previous research [41], the estimated total volume of forest availability was not significantly different. However, this research adapted Korean forest harvesting regulation and examined available forest resources as sawlog and pulp grade wood, respectively. In the near future, there is required to investigate forest resource availability considering socio-economic and environmental constraints, a barrier to the harvesting operation.

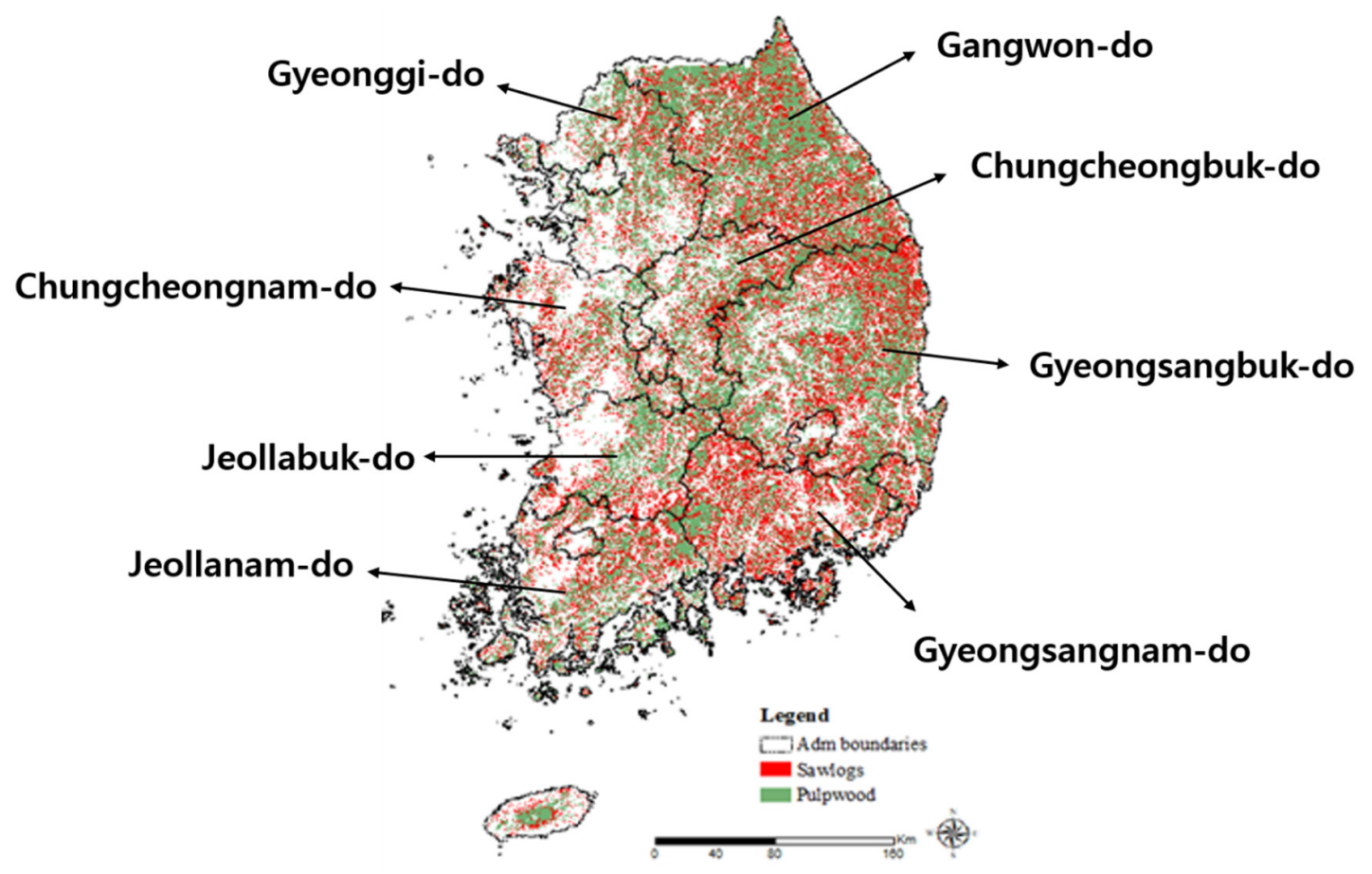

Figure 3. Forecast map of the national-level forest resource availability.

Thousand cubic meter (m3)

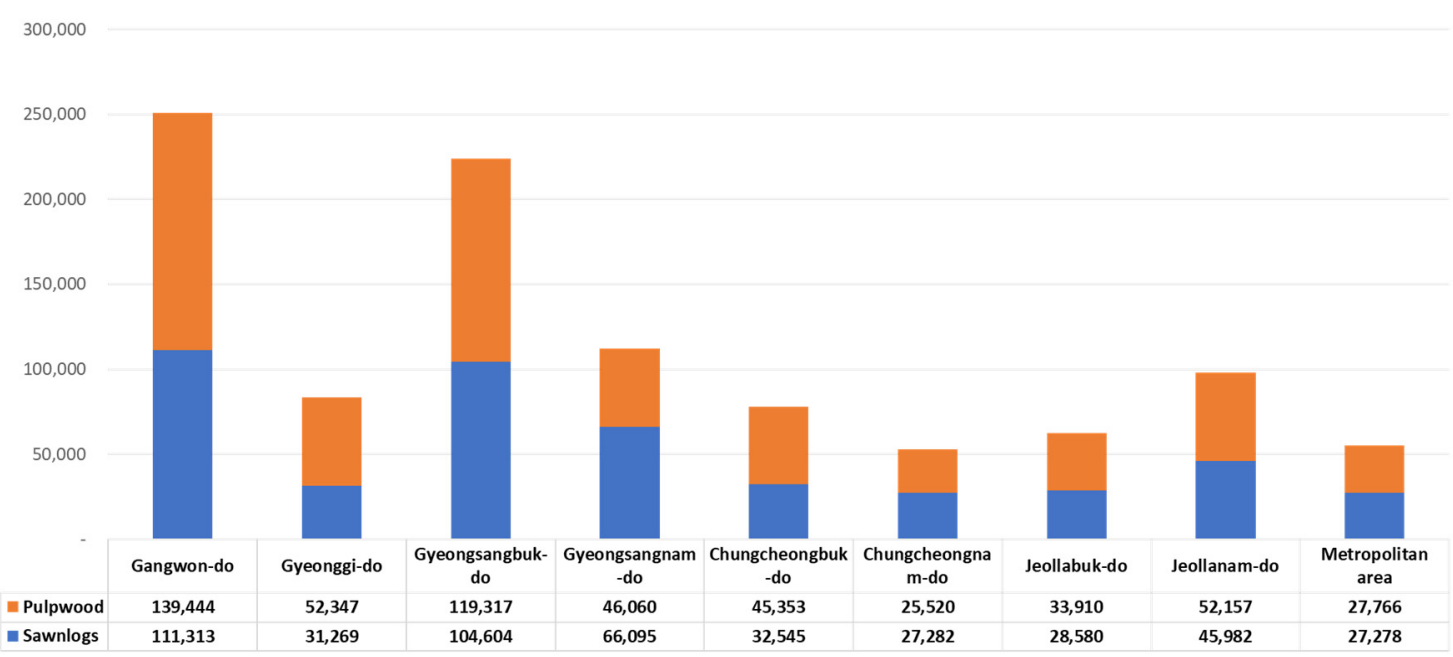

Figure 4. Estimated national-level forest resource availability in thousands of cubic meters. 


\subsection{Identified Locations of Forest Industry Clusters Candidates in South Korea}

As a result of the AHP analysis and pairwise comparison, different weights were given to each main and sub-criteria [30,51]. The estimated weights and the corresponding consistency ratios are presented in Table 6.

Table 6. Analytical hierarchy process (AHP) survey weights and preference factors.

\begin{tabular}{|c|c|c|c|c|c|}
\hline Main Criteria & $\begin{array}{l}\text { Weights } \\
\text { (Criteria) }\end{array}$ & $\begin{array}{l}\text { Second Level: } \\
\text { Sub-Criteria }\end{array}$ & $\begin{array}{c}\text { Weights } \\
\text { (Sub-Criteria) }\end{array}$ & Total Weight & $\begin{array}{c}\text { Consistency } \\
\text { Ratio }\end{array}$ \\
\hline \multirow[t]{3}{*}{ Economic } & \multirow[t]{3}{*}{0.59} & Timber availability & 0.489 & 0.289 & \multirow[t]{3}{*}{0.073} \\
\hline & & Local timber demand & 0.282 & 0.166 & \\
\hline & & Transport logistics & 0.229 & 0.135 & \\
\hline \multirow[t]{3}{*}{ Environmental } & \multirow[t]{3}{*}{0.249} & $\begin{array}{l}\text { Land cover } \\
\text { classification }\end{array}$ & 0.344 & 0.086 & \multirow[t]{3}{*}{0.009} \\
\hline & & $\begin{array}{l}\text { Distance from } \\
\text { industry }\end{array}$ & 0.474 & 0.118 & \\
\hline & & Topographic & 0.182 & 0.045 & \\
\hline \multirow[t]{3}{*}{ Social } & \multirow[t]{3}{*}{0.161} & $\begin{array}{l}\text { Local employment } \\
\text { rate }\end{array}$ & 0.591 & 0.095 & \multirow[t]{3}{*}{0.004} \\
\hline & & Population density & 0.194 & 0.031 & \\
\hline & & $\begin{array}{l}\text { The employment rate } \\
\text { (age) }\end{array}$ & 0.215 & 0.035 & \\
\hline Sum of weights & 1 & & 3 & 1 & \\
\hline
\end{tabular}

The economic factor had the highest weight among the three main criteria. This was most prominent at the second level (sub-criteria), where "Timber availability" was ranked the highest weight (0.289) among all sub-criteria. In the environmental criterion (main criteria level), the "Distance from the industry" was given the highest weight (0.118). Social aspects had the lowest weighted main criterion, and the "Local employment rate" had the highest weight (0.095) compared to "Population density" (0.031) and "Employment rate by age class" (0.035). The consistency ratio showed a high degree of consistency confirming the adequacy of the estimated weight values in Table 6. The AHP results highlighted that the cost-effective timber supply chain is highly required to develop the FIC. Additionally, the role of FIC was expected to create local jobs in the rural area and to revitalize the local economy.

The corresponding weights were adopted in the suitability model development, where the reclassified weights were applied to investigate the final suitability map for the FIC candidates' potential location. Integrated restriction and suitability maps were then computed from raster calculations, which allowed the investigation of final FIC candidate locations. All identified potential locations of FIC candidates, which had the highest suitability value $(\geq 5)$, were selected. Figure 5 presents the identified FIC candidate locations. Five hundred and sixty-five points were identified as suitable locations to construct FIC. The excluded areas were mainly protected, reserved, and restricted areas where construction of FIC is not allowed, such as Baedudaegan mountain reserves and a national park. White cells in Figure 5 represent those restricted areas where FICs cannot be established. The number of final FIC candidates by regions are as follows: Gangwon-do regions $(n=393)$, Jeollabuk-do $(n=52)$, Gyeongsangnam-do $(n=47)$, Chungdheongbuk-do $(n=32)$, Gyeongsangbuk-do $(n=26)$, Gyeonggi-do $(n=8)$, Jeollanam-do $(n=5)$, and Chungcheongnam-do $(n=2)$. 
Restriction

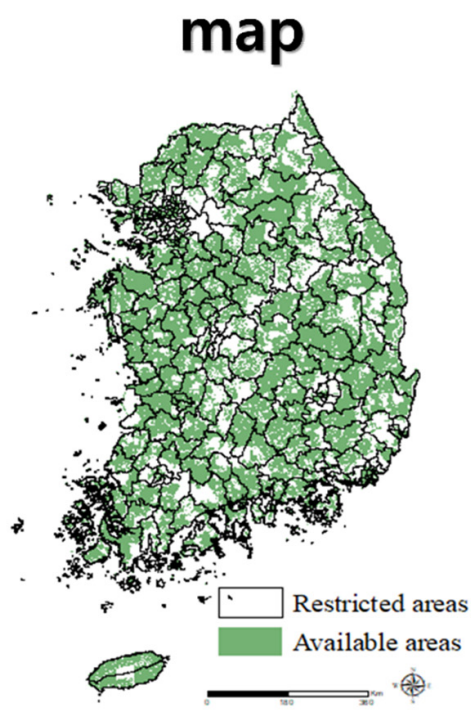

Suitability map

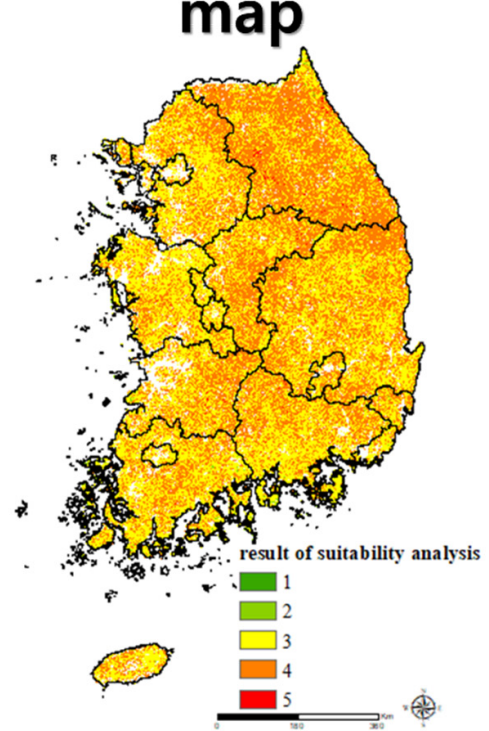

Final FIC candidates

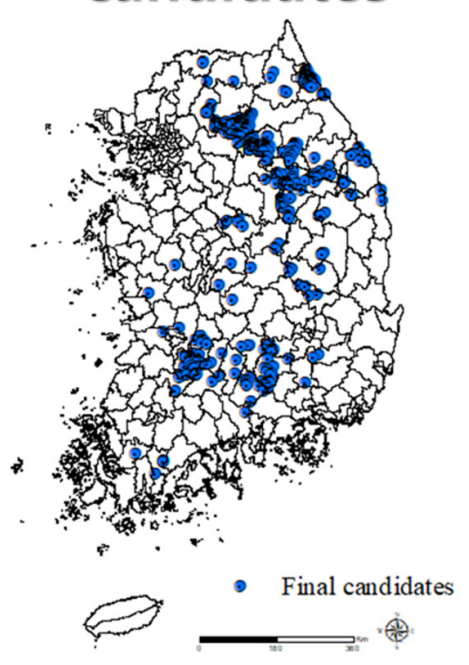

Figure 5. Identified locations of forest industry clusters candidates using developed restriction and suitability models.

\subsection{Identified Optimal Locations of Potential FIC in South Korea}

Figure 6 presents the 12 identified FIC locations that were computed from the candidate locations (565 candidates) by solving the p-median problem that had 164,850 forest resource points. The locationallocation analysis was simulated based on six scenarios, and the detailed information of the scenarios was described in Table 5.

Table 7 shows the simulated transportation costs under different scenarios. Scenario 1 indicated Goesan-gun as the optimal location of FIC. The average transportation distance of this scenario $(141 \mathrm{~km})$ was the longest compared to the other scenarios. Furthermore, scenario 1 was able to reach up to $99 \%$ of forest resource locations available throughout the country. The transportation cost from forest resource locations to the selected FIC, however, was highest among other scenarios due to long transportation distance. The increase of FIC constructions led to a dramatic decrease in the average transportation distance, thus the associated cost decreased. Scenario 2, in which three FICs with a $200 \mathrm{~km}$ transportation radius limit was assumed to be constructed, had a coverage rate reaching approximately $98 \%$ of the total forest available resources. The average distance was about $64 \%(91 \mathrm{~km})$ of that computed in Scenario $1(141 \mathrm{~km})$. The total transportation cost significantly decreased by adding two more FICs in the timber supply chain of the country (Table 7). The most cost-effective number of FIC in the country is 10. If more than 10 FICs were to be constructed, the transportation costs would increase. This is due to the overall transportation distance connecting forest resources and FIC locations, which increases over 10 FICs, thus decreasing the transportation cost efficiency. As expected, the transportation cost was highly influenced by the distance between the FICs and the location of forest resources. 

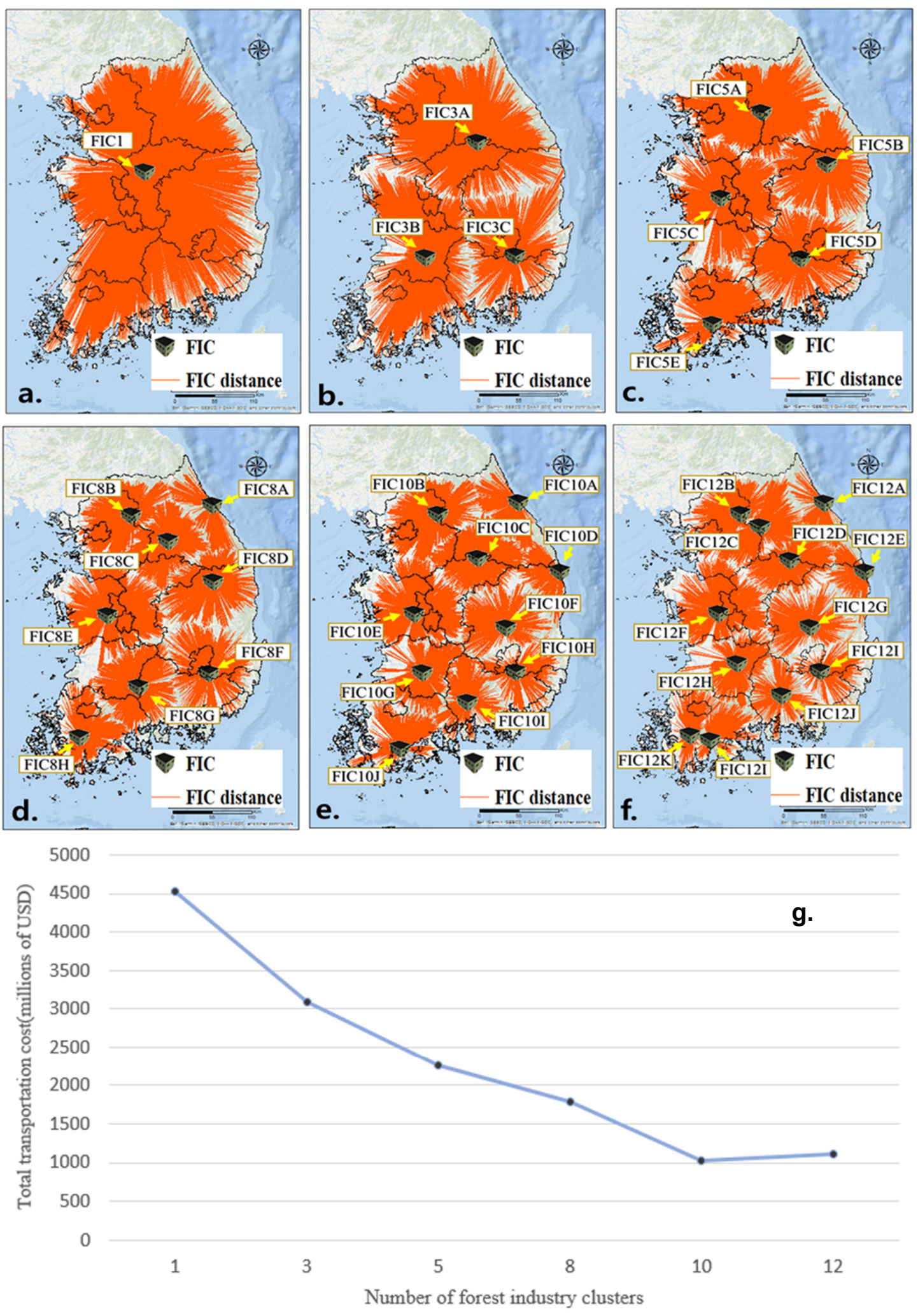

Figure 6. Location and allocation analysis identifying the optimal number and locations for potential forest industry clusters in different scenarios (Each picture indicated the results of Scenario $(\mathbf{a}-\mathbf{f})$ and red lines indicate connections between facilities and location of forest resources, and white boxes represent the location code of each FIC; $(\mathrm{g})$ indicated the variation of total transportation cost with number of plants). 
Table 7. Estimated transportation costs of forest resources depending on the number of FIC locations and their transportation limits.

\begin{tabular}{|c|c|c|c|c|c|c|c|c|c|}
\hline Location Code $^{\text {a }}$ & City Name & $\operatorname{Radius}(\mathbf{k m})^{\mathbf{b}}$ & $\begin{array}{l}\text { Demand } \\
\text { (No.) }^{c}\end{array}$ & $\begin{array}{l}\text { Coverage } \\
\text { Rate(\%) } d\end{array}$ & $\begin{array}{l}\text { Total Area } \\
\text { (ha) }\end{array}$ & $\begin{array}{c}\text { Forest Volume } \\
\text { Availability }\left(\mathrm{m}^{3}\right)^{\mathrm{e}}\end{array}$ & $\begin{array}{l}\text { Ave Distance } \\
(\mathbf{k m})^{\mathrm{f}}\end{array}$ & $\mathrm{USD} / \mathrm{m}^{3} / \mathrm{km}$ & $\begin{array}{c}\text { Total Cost } \\
\text { (Thous USD) } \mathrm{g}\end{array}$ \\
\hline FIC1A & Goesan-gun & 500 & 17,915 & 99 & 188,800 & $39,130,170$ & 141 & 0.82 & $4,526,521$ \\
\hline FIC3A & Jecheon-si & 200 & 9856 & 54 & 106,144 & $22,247,770$ & 101 & 0.82 & $1,851,429$ \\
\hline FIC3B & Imsil-gun & 200 & 5883 & 32 & 60,913 & $12,486,776$ & 92 & 0.82 & 942,672 \\
\hline FIC3C & Cheongdo-gun & 200 & 2155 & 12 & 21,537 & $4,355,947$ & 80 & 0.82 & 286,839 \\
\hline FIC5A & Hongcheon-gun & 150 & 6391 & 35 & 70,835 & $15,202,779$ & 71 & 0.82 & 889,017 \\
\hline FIC5B & Bonghwa-gun & 150 & 2608 & 14 & 27,323 & $5,377,544$ & 77 & 0.82 & 339,635 \\
\hline FIC5C & Gongju-si & 150 & 4687 & 26 & 46,937 & $9,605,629$ & 64 & 0.82 & 503,773 \\
\hline FIC5D & Hapcheon-gun & 150 & 2289 & 13 & 22,743 & $4,635,115$ & 80 & 0.82 & 304,674 \\
\hline FIC5E & Jangheung-gun & 150 & 1935 & 11 & 20,919 & $4,300,325$ & 64 & 0.82 & 227,269 \\
\hline FIC8A & Yangyang-gun & 100 & 627 & 3 & 6223 & $1,253,699$ & 65 & 0.82 & 67,035 \\
\hline FIC8B & Gapyeong-gun & 100 & 3271 & 18 & 34,814 & $7,468,894$ & 51 & 0.82 & 313,770 \\
\hline FIC8C & Hoengseong-gun & 100 & 3063 & 17 & 35,351 & $7,541,616$ & 52 & 0.82 & 324,393 \\
\hline FIC8D & Bonghwa-gun & 100 & 1877 & 10 & 20,133 & $3,968,434$ & 66 & 0.82 & 214,103 \\
\hline FIC8E & Gongju-si & 100 & 3908 & 22 & 39,519 & $8,050,590$ & 57 & 0.82 & 375,681 \\
\hline FIC8F & Cheongdo-gun & 100 & 1359 & 7 & 13,564 & $2,740,918$ & 62 & 0.82 & 139,851 \\
\hline FIC8G & Namwon-si & 100 & 2235 & 12 & 23,545 & $4,858,787$ & 61 & 0.82 & 243,896 \\
\hline FIC8H & Yeongam-gun & 100 & 1160 & 6 & 11,627 & $2,425,884$ & 55 & 0.82 & 109,395 \\
\hline FIC10A & Yangyang-gun & 100 & 954 & 5 & 10,700 & 2246,982 & 74 & 0.82 & 136,147 \\
\hline FIC10B & Gapyeong-gun & 100 & 3741 & 21 & 39,989 & $8,592,063$ & 14 & 0.82 & 100,472 \\
\hline FIC10C & Jecheon-si & 100 & 2962 & 16 & 32,861 & $6,818,676$ & 19 & 0.82 & 105,772 \\
\hline FIC10D & Uljin-gun & 100 & 734 & 4 & 8279 & $1,580,938$ & 96 & 0.82 & 124,280 \\
\hline FIC10E & Gongju-si & 100 & 3437 & 19 & 35,071 & $7,122,147$ & 16 & 0.82 & 91,069 \\
\hline FIC10F & Gunwi-gun & 100 & 1312 & 7 & 12,866 & $2,625,634$ & 43 & 0.82 & 92,141 \\
\hline FIC10G & Imsil-gun & 100 & 1639 & 9 & 15,882 & $3,348,409$ & 32 & 0.82 & 88,144 \\
\hline $\mathrm{FIC} 10 \mathrm{H}$ & Cheongdo-gun & 100 & 846 & 5 & 8581 & $1,743,222$ & 65 & 0.82 & 92,317 \\
\hline FIC10I & Sancheong-gun & 100 & 1006 & 6 & 11,442 & $2,289,663$ & 55 & 0.82 & 103,860 \\
\hline FIC10J & Jangheung-gun & 100 & 1088 & 6 & 11,223 & $2,355,943$ & 47 & 0.82 & 90,826 \\
\hline FIC12A & Yangyang-gun & 100 & 591 & 3 & 6480 & $1,368,522$ & 103 & 0.82 & 115,365 \\
\hline FIC12B & Gapyeong-gun & 100 & 2840 & 16 & 30,328 & $6,515,714$ & 17 & 0.82 & 93,470 \\
\hline FIC12C & Hongcheon-gun & 100 & 2245 & 12 & 26,057 & $5,613,319$ & 21 & 0.82 & 94,458 \\
\hline FIC12D & Jecheon-si & 100 & 2153 & 12 & 23,130 & $4,629,757$ & 24 & 0.82 & 89,881 \\
\hline FIC12E & Uljin-gun & 100 & 627 & 3 & 6603 & $1,268,192$ & 108 & 0.82 & 111,911 \\
\hline FIC12F & Gongju-si & 100 & 3320 & 18 & 33,819 & $6,853,133$ & 16 & 0.82 & 89,458 \\
\hline FIC12G & Gunwi-gun & 100 & 1241 & 7 & 12,120 & $2,471,450$ & 44 & 0.82 & 88,838 \\
\hline
\end{tabular}


Table 7. Cont.

\begin{tabular}{|c|c|c|c|c|c|c|c|c|c|}
\hline Location Code $^{a}$ & City Name & $\operatorname{Radius}(\mathbf{k m})^{\mathbf{b}}$ & $\begin{array}{l}\text { Demand } \\
\text { (No.) }{ }^{c}\end{array}$ & $\begin{array}{l}\text { Coverage } \\
\text { Rate(\%)d }\end{array}$ & $\begin{array}{l}\text { Total Area } \\
\text { (ha) }\end{array}$ & $\begin{array}{c}\text { Forest Volume } \\
\text { Availability }\left(\mathrm{m}^{3}\right)^{\mathrm{e}}\end{array}$ & $\begin{array}{c}\text { Ave Distance } \\
(\mathbf{k m})^{f}\end{array}$ & $\mathrm{USD} / \mathrm{m}^{3} / \mathrm{km}$ & $\begin{array}{c}\text { Total Cost } \\
\text { (Thous USD) } g\end{array}$ \\
\hline FIC12H & Jinan-gun & 100 & 1660 & 9 & 16,077 & $3,420,382$ & 29 & 0.82 & 81,814 \\
\hline FIC12I & Cheongdo-gun & 100 & 713 & 4 & 7166 & $1,448,869$ & 73 & 0.82 & 86,483 \\
\hline FIC12J & Sancheong-gun & 100 & 850 & 5 & 8971 & $1,763,269$ & 58 & 0.82 & 84,310 \\
\hline FIC12K & Yeongam-gun & 100 & 532 & 3 & 5155 & $1,063,276$ & 97 & 0.82 & 84,267 \\
\hline FIC12L & Jangheung-gun & 100 & 970 & 5 & 11,182 & 2347,519 & 47 & 0.82 & 91,400 \\
\hline
\end{tabular}

${ }^{\mathrm{a}}$ Location code of each scenario shown in Table $5 ;^{\mathrm{b}}$ Limitation distance from FICs to forest resources in location-allocation analysis; ${ }^{\mathrm{c}}$ Total number of allocated forest resource locations into identified FIC; ${ }^{\mathrm{d}}$ Forest resource coverage rate of identified FIC (allocated forest resource location/total number of forest resource demand points); ${ }^{\mathrm{e}}$ Total available forest resources in the identified FIC; ${ }^{\mathrm{f}}$ Average travel distance between identified FIC and forest resource locations; ${ }^{\mathrm{g}}$ Assumed truck transportation $\operatorname{cost}, 0.82 \mathrm{USD} / \mathrm{m}^{3} / \mathrm{km}[52]$. 
There have been several previous research studies investigating the optimal location of forestrelated industries including biomass facility [22,30,51] and forest industry clusters [6,53]. Especially in South Korea, Koo et al. (2016) investigated the suitable location of FIC using GIS and economic assessment. However, they did not consider logistic cost from potential forest resources to prospect FIC and constraints of FIC constructions. To overcome these limitations, this research provides the optimal location of prospective FIC in South Korea using potential forest resource availability. Integrated GIS and AHP, along with a timber supply chain cost analysis, were developed to identify the optimal location of FIC.

Internationally, Woo et al. (2018) investigated the optimal location of biomass energy facilities in the Tasmania region by integrating MCA and GIS. They investigated the impact of moisture content on transportation costs using local truck costs per tonne and kilometer. Furthermore, Delivand et al. (2015) examined optimal locations of bioenergy facilities with minimized transportation costs and greenhouse gas emissions in South Italy. They simulated greenhouse gas emission along the timber supply chain using location and allocation analysis results. Compared to both cases, a major weakness of this research is that there were no pre-existing data along the timber supply chain, including greenhouse gas emission, moisture contents, and cost of truck transportation in South Korea.

In future studies, considerable efforts in greenhouse gas emission along the timber supply chain and economic assessment of FIC are required to widely investigate the efficiency and impact of FIC for the South Korea conditions. Furthermore, the cost analysis model has a limit because it does not consider the facility investment cost (i.e., construction cost) and FIC capacity that may affect the optimal number and FIC locations. Thus, the construction cost and FIC size need to be taken into account for more practical design of FIC locations in the future.

\section{Conclusions}

This research investigated the optimal location of FICs in South Korea. It aimed to improve the national forest supply chain and increase the country's domestic timber value. The potential locations of prospective FICs were investigated using restriction and suitability models. To determine the optimal locations of FICs, an integrated AHP and GIS model were developed. The results show that South Korea has enough forest resources to operate a number of FICs. The scenario-based analysis highlighted that 10 FICs with a $100 \mathrm{~km}$ radius was the best option to minimize overall transportation costs from the forest resource to cluster location. From the supply chain perspective, we found that the distance between forest resources and potential FIC locations was identified as the most impacting factor on transportation cost. However, a practical management planning approach considering FIC operation and investment costs, as well as harvesting cost, is further required in future research to adequately quantify the impact of FIC location and number on overall supply chain costs.

Author Contributions: Conceptualization, J.P. and H.W.; methodology, J.P. and H.W.; validation, H.H., B.K. and S.C.; formal analysis, H.W. and G.J.; investigation, H.W.; resources, H.H., J.R., and S.C.; data curation, H.W. and G.J.; writing—original draft preparation, H.W.; writing—review and editing, J.P. and H.H.; visualization, S.C.; supervision, J.P. and H.K.W.; project administration, J.P. and H.K.W.; funding acquisition, J.P. All authors have read and agreed to the published version of the manuscript. Please turn to the CRediT taxonomy for the term explanation. Authorship must be limited to those who have contributed substantially to the work reported.

Funding: This research was funded by the Korea Forest Service (Korea Forestry Promotion Institute) [project nos. 2019149C10-2023-0301, 2018112B10-2020-BB01].

Conflicts of Interest: The authors declare no conflict of interest.

\section{References}

1. Carlsson, D.; Rönnqvist, M. Supply chain management in forestry-Case studies at Södra Cell AB. Eur. J. Oper. Res. 2005, 163, 589-616. [CrossRef]

2. Bettinger, P.; Boston, K.; Siry, J.P.; Grebner, D.L. Forest Management and Planning; Academic Press: Cambridge, MA, USA, 2016. 
3. Shapiro, J. Modeling the Supply Chain; Nelson Education: Toronto, ON, Canada, 2006.

4. Tayur, S.; Ganeshan, R.; Magazine, M. Quantitative Models for Supply Chain Management; Springer Science \& Business Media: Berlin, Germany, 2012; Volume 17.

5. Zhang, F.; Johnson, D.M.; Sutherland, J.W. A GIS-based method for identifying the optimal location for a facility to convert forest biomass to biofuel. Biomass Bioenergy 2011, 35, 3951-3961. [CrossRef]

6. Koo, J.C. Enhancing Productivity of Domestic Wood through Industrial Clusters; Korea Forest Service, Ed.; Korea Forest Service: Daejeon, Korea, 2016.

7. Sandberg, D.; Vasiri, M.; Trischler, J.; Öhman, M. The role of the wood mechanical industry in the Swedish forest industry cluster. Scand. J. For. Res. 2014, 29, 352-359. [CrossRef]

8. Han, H.; Seol, A.; Jung, Y.; Chung, J. Maintaining long-rotation forestry: A new challenge for sustained yield of timber resources in South Korea. Int. For. Rev. 2018, 20, 199-205. [CrossRef]

9. Korea Forest Service. Statistical Yearbook of Forestry; Korea Forest Service: Daejeon, Korea, 2019.

10. MacDicken, K.G. Global forest resources assessment 2015: What, why and how? For. Ecol. Manag. 2015, 352, 3-8. [CrossRef]

11. Lee, D.K.; Lee, Y.K. Roles of Saemaul Undong in reforestation and NGO activities for sustainable forest management in Korea. J. Sustain. For. 2005, 20, 1-16. [CrossRef]

12. Choi, S.-W. Diversity and composition of larger moths in three different forest types of Southern Korea. Ecol. Res. 2008, 23, 503-509. [CrossRef]

13. Korea Forest Service. The 6th Basic Forest Plan; Korea Forest Service: Daejeon, Korea, 2018.

14. Yu, S.; Park, J.; Kim, M.; Kim, H.; Ryu, C.; Lee, Y.; Yang, W.; Jeong, Y.-G. Improving energy density and grindability of wood pellets by dry torrefaction. Energy Fuels 2019, 33, 8632-8639. [CrossRef]

15. Korea Forest Service. Wood Supply Plan; Korea Forest Service: Daejeon, Korea, 2018.

16. Min, K.; Seok, H.D.; Choi, J.Y. Policy Tasks to Improve the Profitability of Forest Management in Korea; Korea Rural Economic Institute, Ed.; Korea Rural Economic Institute: Naju, Korea, 2018.

17. Kim, K.D. A Study on the Policy of Sustainable Domestic Timber Supply Using Delphi Technique and AHP. In Forestry; Kyungpook National University: Daegu, Korea, 2012; p. 133.

18. Korea Forest Service. A Survey on the Actual Condition of Timber Use in South Korea; Korea Forest Service, Ed.; Korea Forest Service: Daejeon, Korea, 2011.

19. Kim, J.; Choi, S.; Kim, C.; Kim, W. Analysis of Wood Distribution Structure; Korea Forest Service, Ed.; Korea Forest Service: Daejeon, Korea, 2005; p. 87.

20. Kim, C.; Park, Y.; Kim, J.; Choi, S. Trends of Wood Industry and Analysis of Impacts on Log Demand and Supply in 2005. J. Korean For. Econ. 2006, 14, 13-22.

21. Woo, H. Forestry Biomass Residue Supply Chains in Tasmania: Developing a Digital Tool and Enhancing Modelling to Improve Data Accuracy, Location Mapping and Impact Assessments for Future Bioenergy; University of Tasmania: Hobart, Australia, 2020.

22. Noon, C.E.; Daly, M.J. GIS-based biomass resource assessment with BRAVO. Biomass Bioenergy 1996, 10, 101-109. [CrossRef]

23. Burak, A.; Harry, C.; David, W.; Kevin, G.; Sujith, S.; Mario, E.; Norman, S. Woody biomass and mill waste utilization opportunities in Alabama: Transportation cost minimization, optimum facility location, economic feasibility, and impact. Environ. Prog. Sustain. Energy 2011, 30, 720-732. [CrossRef]

24. Köhl, M.; Magnussen, S.S.; Marchetti, M. Sampling Methods, Remote Sensing and GIS Multiresource Forest Inventory; Springer Science \& Business Media: Berlin, Germany, 2006.

25. Wijaya, A.; Kusnadi, S.; Gloaguen, R.; Heilmeier, H. Improved strategy for estimating stem volume and forest biomass using moderate resolution remote sensing data and GIS. J. For. Res. 2010, 21, 1-12. [CrossRef]

26. Chirici, G.; Barbati, A.; Maselli, F. Modelling of Italian forest net primary productivity by the integration of remotely sensed and GIS data. For. Ecol. Manag. 2007, 246, 285-295. [CrossRef]

27. Yoshioka, T.; Sakai, H. Amount and availability of forest biomass as an energy resource in a mountainous region in Japan: A GIS-based analysis. Croat. J. For. Eng. J. Theory Appl. For. Eng. 2005, 26, 59-70.

28. Devlin, G.J.; McDonnell, K.; Ward, S. Timber haulage routing in Ireland: An analysis using GIS and GPS. J. Transp. Geogr. 2008, 16, 63-72. [CrossRef]

29. Dean, D.J. Finding optimal routes for networks of harvest site access roads using GIS-based techniques. Can. J. For. Res. 1997, 27, 11-22. [CrossRef] 
30. Woo, H.; Acuna, M.; Moroni, M.; Taskhiri, M.; Turner, P. Optimizing the location of biomass energy facilities by integrating Multi-Criteria Analysis (MCA) and Geographical Information Systems (GIS). Forests 2018, 9, 585. [CrossRef]

31. Yue, C.-D.; Yang, G.G.-L. Decision support system for exploiting local renewable energy sources: A case study of the Chigu area of southwestern Taiwan. Energy Policy 2007, 35, 383-394. [CrossRef]

32. Buchholz, T.; Rametsteiner, E.; Volk, T.A.; Luzadis, V.A. Multi criteria analysis for bioenergy systems assessments. Energy Policy 2009, 37, 484-495. [CrossRef]

33. Van Dael, M.; Van Passel, S.; Pelkmans, L.; Guisson, R.; Swinnen, G.; Schreurs, E. Determining potential locations for biomass valorization using a macro screening approach. Biomass Bioenergy 2012, 45, 175-186. [CrossRef]

34. Perpiña, C.; Martínez-Llario, J.C.; Pérez-Navarro, Á. Multicriteria assessment in GIS environments for siting biomass plants. Land Use Policy 2013, 31, 326-335. [CrossRef]

35. Mourmouris, J.; Potolias, C. A multi-criteria methodology for energy planning and developing renewable energy sources at a regional level: A case study Thassos, Greece. Energy Policy 2013, 52, 522-530. [CrossRef]

36. Boggia, A.; Cortina, C. Measuring sustainable development using a multi-criteria model: A case study. J. Environ. Manag. 2010, 91, 2301-2306. [CrossRef] [PubMed]

37. Wang, J.-J.; Jing, Y.-Y.; Zhang, C.-F.; Zhao, J.-H. Review on multi-criteria decision analysis aid in sustainable energy decision-making. Renew. Sustain. Energy Rev. 2009, 13, 2263-2278. [CrossRef]

38. Massimo, M. Optimal plant size and feedstock supply radius: Minimize the production or maximize the profits? In Proceedings of the 20th European Biomass Conference and Exhibition, Milan, Italy, 18-22 June 2012; pp. 1-7.

39. Korea Forest Service. Wood Grade Standard; Korea Forest Service: Daejeon, Korea, 2019; Notice 2017-97.

40. Saaty, T.L. Decision making with the analytic hierarchy process. Int. J. Serv. Sci. 2008, 1, 83-98. [CrossRef]

41. Won, H.K.; Jang, K.M.; Kim, Y.H.; Lee, K.H.; Kim, H.H. Estimation of Potential Wood Supply by according to Geographical and Forest Management Conditions in Korea. J. Agric. Life Sci. 2011, 45, 35-41.

42. Yeong-Hwan, K.; Eo-Jin, J.; Yong, S.M.; Il-Bin, C.; Sangtae, L.; Kyungwon, S.; Jungkee, P. A Study on the Baseline Carbon Stock for Major Species in Korea for Conducting Carbon Offset Projects based on Forest Management. J. Korean Soc. For. Sci. 2014, 103. [CrossRef]

43. Son, Y.; Kim, R.; Lee, K.; Pyo, J.; Kim, S.; Hwang, J.; Lee, S.; Park, H. Carbon Emission Factors and Biomass Allometric Equations by Species in Korea; Korea Forest Research Institute: Seoul, Korea, 2014.

44. Mickler, R.A.; Earnhardt, T.S.; Moore, J.A. Regional estimation of current and future forest biomass. Environ. Pollut. 2002, 116, S7-S16. [CrossRef]

45. Korea Forest Service. Forest Geospatial Information System. Available online: http://data.forest.go.kr (accessed on 3 January 2020).

46. MOLIT. Enforcement Rules of the Law on Planning and Utilization of National Territory. In 1438; Ministry of Land, Infrastructure and Transport: Seoul, Korea, 2018.

47. Analyst, A.S. Advanced GIS Spatial Analysis Using Raster and Vector Data; Environmental System Research Institute: New York, NY, USA, 2001.

48. Sultana, A.; Kumar, A. Optimal siting and size of bioenergy facilities using geographic information system. Appl. Energy 2012, 94, 192-201. [CrossRef]

49. Daskin, M.S. Network and Discrete Location: Models, Algorithms, and Applications; John Wiley \& Sons: NewYork, NY, USA, 2011.

50. ESRI. Algorithm Used by Network Analyst; ESRI: Redlands, CA, USA, 2011.

51. Delivand, M.K.; Cammerino, A.R.B.; Garofalo, P.; Monteleone, M. Optimal locations of bioenergy facilities, biomass spatial availability, logistics costs and GHG (greenhouse gas) emissions: A case study on electricity productions in South Italy. J. Clean. Prod. 2015, 99, 129-139. [CrossRef]

52. Korea Forest Service. The Quarterly Market Prices of Domestic Timber; Korea Forest Service, Ed.; Korea Forestry Promotion Institute (KOFPI): Daejeon, Korea, 2019; pp. 2288-7369.

53. Ogunwusi, A.; Ifeyinwa, O. Enhancing Productivity of Forest Industry through Industrial Clusters Concept. Ind. Eng. Lett. 2012, 2, 19-29.

(C) 2020 by the authors. Licensee MDPI, Basel, Switzerland. This article is an open access article distributed under the terms and conditions of the Creative Commons Attribution (CC BY) license (http://creativecommons.org/licenses/by/4.0/). 